Review Article

\title{
The Silent Pandemic: The Psychological Burden on Frontline Healthcare Workers during COVID-19
}

\author{
Luise J. Froessl $(\mathbb{D}$ and Yazan Abdeen \\ Pulmonary and Sleep Physicians of Houston, P.A. 501 Orchard Street, Webster, TX 77589, USA \\ Correspondence should be addressed to Luise J. Froessl; luisefroessl@gmail.com
}

Received 7 August 2021; Accepted 14 September 2021; Published 30 September 2021

Academic Editor: Lenin Pavon

Copyright (c) 2021 Luise J. Froessl and Yazan Abdeen. This is an open access article distributed under the Creative Commons Attribution License, which permits unrestricted use, distribution, and reproduction in any medium, provided the original work is properly cited.

This narrative review explores the full scope of harmful psychological effects of the COVID-19 (Coronavirus Disease of 2019) pandemic on FLHCWs (Frontline healthcare workers). Additionally, we highlight the risk factors for worse outcomes. A literature review identified 24 relevant papers included in this synthesis. The majority of studies reported a high number of mental health conditions in HCWs (Healthcare workers) overall. Working in the frontline setting was repeatedly identified as an independent risk factor for poorer mental health. Additional risk factors, such as gender, occupational pressure, and low level of support from hospital administration, family, and the community, were also commonly identified. In the past, defined interventions have been shown to mitigate the psychological impact of high-stress situations on frontline workers. This review is aimed at identifying individuals at higher risk to help effectively target preventative measures in future stress situations in our healthcare system.

\section{Introduction}

On March $11^{\text {th }}, 2020$, the WHO (World Health Organization) officially declared the COVID-19 outbreak a global pandemic, a mere four months after identifying the first cases of SARS-CoV-2 (Severe acute respiratory syndrome coronavirus 2) in Wuhan, China. The pandemic has had severe, wide-reaching effects on the functioning of societies, economies, and healthcare systems globally [1]. In addition to the ongoing health crisis, a correlated mental health crisis has been unfolding [2]. An online survey of the U.S. general population conducted in March 2020 found that almost half of the participants met the criteria for anxiety or depression, compared to a baseline rate of these conditions of about $19 \%$ and $24 \%$, respectively [3]. The purpose of this narrative review is to summarize the deleterious psychological effects of the COVID-19 pandemic on FLHCWs (Frontline healthcare workers) as reported by existing literature. The ultimate goal is to facilitate the development and implementation of preventative measures for the future.
Medical and paramedical staff who work directly with COVID-19-infected patients make up FLHCWs. These individuals are a crucial element in the medical response to a global pandemic and are simultaneously uniquely vulnerable to the psychological stresses imposed by the pandemic. They have been faced with novel challenges in the workplace, all while adjusting to the same changes in daily life as the general public.

The studies included in this review commonly evaluated the prevalence of the following mental health conditions. GAD (Generalized Anxiety Disorder) is defined by the DSM-V (Diagnostic and Statistical Manual of Mental Disorders) as the existence of excessive worry or apprehensive expectation about an event or activity that is difficult to control associated with defined physical symptoms [4]. A depressed mood, or anhedonia, in association with defined somatic or nonsomatic symptoms, characterizes major depressive disorder [5]. PTSD (Post-traumatic stress disorder) is defined as the development of negative emotional and behavioral symptoms in response to exposure to actual 
or threatened death, serious injury, or sexual violence [6]. Burnout is a work-related syndrome that Maslach et al. define by three dimensions: exhaustion, cynicism, and inefficacy [7]. Insomnia, a complaint of dissatisfaction with sleep quantity or quality, and its relationship to the previously mentioned conditions were also frequently evaluated [8].

Adverse psychological impacts on FLHCW have previously been reported during emergent viral epidemics such as the SARS-CoV-1 (Severe acute respiratory syndrome coronavirus 1), MERS (Middle East Respiratory Syndrome), or swine flu outbreaks [9, 10]. McAlonan et al. additionally reported that stress levels were higher in SARS FLHCWs one year after the initial exposure [11].

\section{Methods}

The PRISMA (Preferred reporting items for systematic reviews and meta-analyses) methodology checklist was used as a guideline to adequately identify and select the relevant literature for this narrative review. Searches of PubMed and Google Scholar were conducted from December $20^{\text {th }}$, 2020 , to January $27^{\text {th }}, 2021$. The following keywords were entered in various combinations: "COVID-19," "pandemic," "coronavirus," "healthcare worker," "frontline," "psychiatric," "psychological," "mental," "stress," and "mental health." The bibliographies of relevant papers were also reviewed manually to extract additional literature of interest. Of the results, 24 studies were included in this review. Only studies that were available in the English language and published in peer-reviewed journals were included. Studies with a sample size of fewer than 100 participants or review papers, meta-analyses, editorials, and commentaries were not considered for inclusion.

\section{Results}

A review of the literature resulted in the identification of 24 relevant papers examining the psychological effects of the pandemic on FLHCWs (Table 1). Twenty-three of these papers used a cross-sectional, observational design and were conducted using an online survey completed by voluntary participants [12-34]. The remaining study was a matched cross-sectional study [35]. The number of participants included in each study ranged from 126 to 2285 . The studies identified for this review originate from 10 different countries. Four studies included exclusively frontline workers $[16,26,28,33]$; the rest consisted of healthcare workers with a subgroup of frontline workers. All but one study employed objective and scientifically verified scales to measure the presence of anxiety, depression, insomnia, and stress symptoms in included participants. Some also used additional questions or scales to evaluate perceived stress, PTSD, or other psychological factors.

All included studies found that adverse psychological effects were highly prevalent in healthcare workers. In most studies, direct contact with confirmed or suspected COVID19 patients was an independent risk factor for adverse mental health outcomes. However, four of the 24 included papers showed no significant difference or a lower prevalence of mental health issues in the FLHCW group [15, 24, 27, 30].

The GAD-7 (Generalized Anxiety Disorder 7) and the PHQ-9 (Patient Health Questionnaire 9) were the most commonly employed scales used to evaluate participants for anxiety and depression, respectively. However, other scales such as the HADS (Hospital Anxiety and Depression Scale) or the DASS-21 (Depression, Anxiety, and Stress Scale 21) were also used. In the studies evaluated in this review, the anxiety was present in $15-50 \%$ of healthcare workers. The majority, but not all surveys, detected higher levels of anxiety in FLHCWs vs. non-FLHCWs. Cag et al. conducted a large-scale international study in March 2020 and found that $2 / 3$ of FLHCWs screened positive for anxiety, with $17 \%$ showing severe anxiety levels [29]. Depression or depressive symptoms were detected in $15-65 \%$ of individuals depending on the study. Overall, FLHCWs were found to have significantly higher levels of anxiety and depression than HCWs. Significantly, one paper reported the significant association of depression with lower quality of life in the frontline nurses [16]. Additional risk factors were also examined. Being of female gender or being of younger age is an additional risk factor identified by multiple studies [18, 20, $29,30,34]$. A history of chronic illness or having a mental disorder predisposed the individual to poor mental health [20]. Having experienced patient death from COVID-19 or the death of a close family member or friend from COVID-19 increased risk as well [20,34].

Several studies reported posttraumatic symptoms and a perceived need for psychological support in healthcare workers. The risk for these conditions was independently associated with participating in frontline work [34].

Studies reported high levels of burnout in healthcare workers in Spain, Italy, Belgium, and China [19, 30, 31, 33].

The prevalence of insomnia in FLHCWs was also evaluated by several studies $[14,15,17,26,28]$. Three validated questionnaires were used to assess participants for insomnia: the ISI (Insomnia Severity Index), the PSQI (Pittsburgh Sleep Quality Index), and the AIS (Athens Insomnia Scale). Insomnia was common, with a prevalence of $35-75 \%$. As reported with anxiety, depression, and other mental health symptoms, insomnia was also significantly more prevalent in medical professionals working directly with COVID-19 patients [35].

\section{Discussion}

4.1. Challenging Conditions for FLHCWs. Besides being exposed to the same mental stressors and societal shifts as the public, FLHCWs have faced many additional challenges due to the pandemic. Secondary to the nature of their work, they are burdened with a greater personal risk of exposure and of exposing family members. In addition, they face higher workloads, moral dilemmas, and the challenges that come with caring for acutely ill patients in their workplace [36].

A prospective, observational cohort study conducted among the American and British general public in March 2020 found that FLHCW had a significantly increased risk of testing positive for COVID-19 [37]. In the early stages 
TABLE 1

\begin{tabular}{|c|c|c|c|c|}
\hline Reference & $\begin{array}{l}\text { Location and } \\
\text { date range }\end{array}$ & Study type & $\begin{array}{l}\text { Sample } \\
\text { size }\end{array}$ & Topic of study \\
\hline $\begin{array}{l}\text { Conti et al. } \\
2020 \text { [34] }\end{array}$ & $\begin{array}{l}\text { Italy } \\
\text { March } 30^{\text {th }} \text { to } \\
\text { May } 5^{\text {th }} 2020\end{array}$ & $\begin{array}{l}\text { Online } \\
\text { cross- } \\
\text { sectional } \\
\text { survey }\end{array}$ & 933 HCWs & $\begin{array}{c}\text { Mental health status and psychological } \\
\text { care needs of HCWs during the } \\
\text { COVID-19 pandemic }\end{array}$ \\
\hline $\begin{array}{l}\text { Trumello } \\
\text { et al. } 2020 \\
{[12]}\end{array}$ & $\begin{array}{c}\text { Italy } \\
\text { April } 11^{\text {th }} \text { to } \\
\text { April } 16^{\text {th }} \\
2020\end{array}$ & $\begin{array}{l}\text { Online } \\
\text { cross- } \\
\text { sectional } \\
\text { survey }\end{array}$ & 627 HCWs & $\begin{array}{l}\text { Psychological adjustment in HCW } \\
\text { during the COVID-19 pandemic, the } \\
\text { effect of frontline work }\end{array}$ \\
\hline
\end{tabular}

\begin{tabular}{|c|c|c|c|c|}
\hline ue et $a$ & $\begin{array}{l}\text { China } \\
\text { February } 16^{\text {th }} \\
\text { to February } \\
23^{\text {rd }} 2020\end{array}$ & $\begin{array}{l}\text { Online } \\
\text { cross- } \\
\text { sectional } \\
\text { survey }\end{array}$ & $\begin{array}{c}2285 \\
\text { HCWs }\end{array}$ & $\begin{array}{l}\text { Risk factors for the development of } \\
\text { psychological problems in different } \\
\text { groups of HCWs during the COVID- } \\
19 \text { pandemic }\end{array}$ \\
\hline
\end{tabular}

Key outcomes

(i) Poorer mental health: female gender, age $<40$ years, having experienced death of a patient

(ii) Lesser but significant effect on mental health: working in a highly infected area, frontline work

\section{(i) Higher psychological impact in} FLHCWs

(ii) Demand for psychological support is double in FLHCWs vs. non-FLHCWs

(i) Poorer mental health: frontline work, receiving negative information about the pandemic, receiving negative feedback from family or friends

(ii) Higher risk in nurses, paramedical professionals, lower risk in medical residents

\begin{tabular}{|c|c|c|c|c|c|}
\hline $\begin{array}{l}\text { Qi et al. } \\
2020[14]\end{array}$ & $\begin{array}{l}\text { China } \\
\text { February } \\
2020\end{array}$ & $\begin{array}{l}\text { Online } \\
\text { cross- } \\
\text { sectional } \\
\text { survey }\end{array}$ & $\begin{array}{l}1306 \\
\text { HCWs }\end{array}$ & $\begin{array}{c}\text { Sleep disturbances and mental health } \\
\text { in FLHCWs compared to non- } \\
\text { FLHCWs during the COVID-19 } \\
\text { pandemic }\end{array}$ & $\begin{array}{l}\text { (i) Poorer mental health: FLHCWs, } \\
\text { female gender } \\
\text { (ii) Anxiety and depression associated } \\
\text { with poor sleep quality }\end{array}$ \\
\hline $\begin{array}{l}\text { Jahrami } \\
\text { et al. } 2020 \\
{[15]}\end{array}$ & $\begin{array}{l}\text { Bahrain } \\
\text { April } 2020\end{array}$ & $\begin{array}{l}\text { Online } \\
\text { cross- } \\
\text { sectional } \\
\text { survey }\end{array}$ & 257 HCWs & $\begin{array}{l}\text { Sleep quality in FLHCWs as compared } \\
\text { to non-FLHCWs during the COVID- } \\
19 \text { pandemic }\end{array}$ & $\begin{array}{l}\text { (i) High prevalence of poor sleep quality, } \\
\text { no significant difference between FL and } \\
\text { non-FLHCWs } \\
\text { (ii) Sex and professional background are } \\
\text { most predictive of poor sleep quality }\end{array}$ \\
\hline $\begin{array}{l}\text { An et al. } \\
2020[16]\end{array}$ & $\begin{array}{l}\text { China } \\
\text { March } 15^{\text {th }} \text { to } \\
\text { March } 20^{\text {th }} \\
2020\end{array}$ & $\begin{array}{l}\text { Online } \\
\text { cross- } \\
\text { sectional } \\
\text { survey }\end{array}$ & $\begin{array}{l}1103 \mathrm{ED} \\
\text { nurses }\end{array}$ & $\begin{array}{c}\text { Prevalence of depression and quality of } \\
\text { life in ED nurses during the COVID-19 } \\
\text { pandemic }\end{array}$ & $\begin{array}{l}\text { (i) Frontline nurses: higher depression, } \\
\text { lower quality of life }\end{array}$ \\
\hline $\begin{array}{l}\text { Cai et al. } \\
2020[35]\end{array}$ & $\begin{array}{l}\text { China } \\
\text { February } 11^{\text {th }} \\
\text { to February } \\
26^{\text {th }} 2020\end{array}$ & $\begin{array}{l}\text { Online, } \\
\text { case-control, } \\
\text { matched }\end{array}$ & $\begin{array}{l}1173 \\
\text { FLHCW } \\
\text { vs. } 1173 \\
\text { non- } \\
\text { FLHCW }\end{array}$ & $\begin{array}{l}\text { Comparison of the pandemic's } \\
\text { psychological impact on FLHCWs vs. } \\
\text { non-FLHCW }\end{array}$ & $\begin{array}{l}\text { (i) Poorer mental health and insomnia in } \\
\text { FLHCWs } \\
\text { (ii) No significant difference in help- } \\
\text { seeking behavior }\end{array}$ \\
\hline $\begin{array}{l}\text { Zhang } \\
\text { et al. } 2020 \\
{[17]}\end{array}$ & $\begin{array}{l}\text { China } \\
\text { January } 29^{\text {th }} \\
\text { to February } \\
3^{\text {rd }} 2020\end{array}$ & $\begin{array}{l}\text { Online, } \\
\text { cross- } \\
\text { sectional } \\
\text { survey }\end{array}$ & $\begin{array}{l}1563 \\
\mathrm{HCW}\end{array}$ & $\begin{array}{l}\text { Insomnia and related psychological } \\
\text { and social factors in HCWs during the } \\
\text { COVID-19 pandemic }\end{array}$ & $\begin{array}{l}\text { (i) } 1 / 3 \text { medical workers included had } \\
\text { insomnia } \\
\text { (ii) Increased risk for insomnia: work in } \\
\text { isolation wards, lower level of education, } \\
\text { worry of being infected, uncertainty about } \\
\text { effectiveness of infection control } \\
\text { measures }\end{array}$ \\
\hline $\begin{array}{l}\text { Elbay et al. } \\
2020[18]\end{array}$ & $\begin{array}{l}\text { Turkey } \\
\text { March } 10^{\text {th }} \text { to } \\
\text { March } 15^{\text {th }}\end{array}$ & $\begin{array}{l}\text { Online, } \\
\text { cross- } \\
\text { sectional } \\
\text { survey }\end{array}$ & $\begin{array}{c}442 \\
\text { physicians }\end{array}$ & $\begin{array}{c}\text { Anxiety, depression, and stress in } \\
\text { physicians during the COVID-19 } \\
\text { pandemic }\end{array}$ & $\begin{array}{l}\text { (i) DAS-21 was higher in FLHCWs } \\
\text { (ii) Poorer mental health: female gender, } \\
\text { young age, frontline work, less work } \\
\text { experience }\end{array}$ \\
\hline $\begin{array}{l}\text { Macía- } \\
\text { Rodríguez } \\
\text { et al. } 2021 \\
{[19]}\end{array}$ & $\begin{array}{c}\text { Spain } \\
\text { May } 2020\end{array}$ & $\begin{array}{l}\text { Online, } \\
\text { cross- } \\
\text { sectional } \\
\text { survey }\end{array}$ & $\begin{array}{l}1015 \\
\text { HCWs }\end{array}$ & $\begin{array}{c}\text { Impact of the COVID-19 outbreak on } \\
\text { mental health and burnout syndrome } \\
\text { in internists }\end{array}$ & $\begin{array}{l}\text { (i) Higher burnout levels in FLHCWs, } \\
\text { insufficient PPE, worry about infecting } \\
\text { family, OH consumption, increased } \\
\text { responsibility, longer work hours, and no } \\
\text { rest }\end{array}$ \\
\hline
\end{tabular}


TABle 1: Continued.

\begin{tabular}{|c|c|c|c|c|}
\hline Reference & $\begin{array}{l}\text { Location and } \\
\text { date range }\end{array}$ & Study type & $\begin{array}{l}\text { Sample } \\
\text { size }\end{array}$ & Topic of study \\
\hline $\begin{array}{l}\text { Erquicia } \\
\text { et al. } 2020 \\
{[20]}\end{array}$ & $\begin{array}{l}\text { Spain } \\
\text { March to } \\
\text { April } 2020\end{array}$ & $\begin{array}{l}\text { In-person, } \\
\text { cross- } \\
\text { sectional } \\
\text { survey }\end{array}$ & 395 HCWs & $\begin{array}{l}\text { Analysis of the emotional state of } \\
\text { healthcare professionals during the } \\
\text { COVID-19 pandemic }\end{array}$ \\
\hline $\begin{array}{l}\text { Si et al. } \\
2020[21]\end{array}$ & $\begin{array}{l}\text { China } \\
\text { February } 23^{\text {rd }} \\
\text { to March } 5^{\text {th }} \\
2020\end{array}$ & $\begin{array}{l}\text { Online, } \\
\text { cross- } \\
\text { sectional } \\
\text { survey }\end{array}$ & 863 HCWs & $\begin{array}{l}\text { Psychological impact of the COVID-19 } \\
\text { pandemic on HCWs }\end{array}$ \\
\hline $\begin{array}{l}\text { Xia et al. } \\
2021 \text { [22] }\end{array}$ & $\begin{array}{c}\text { China } \\
\text { February } 3^{\text {rd }} \\
\text { to March } 30^{\text {th }} \\
\quad 2020\end{array}$ & $\begin{array}{l}\text { Online, } \\
\text { cross- } \\
\text { sectional } \\
\text { survey }\end{array}$ & 126 HCWs & $\begin{array}{l}\text { Psychological impact and coping } \\
\text { mechanisms in medical staff during the } \\
\text { COVID-19 pandemic }\end{array}$ \\
\hline $\begin{array}{l}\text { Hennein } \\
\text { et al. } 2021 \\
{[23]}\end{array}$ & $\begin{array}{c}\text { USA } \\
\text { May } 2020\end{array}$ & $\begin{array}{l}\text { Online, } \\
\text { cross- } \\
\text { sectional } \\
\text { survey }\end{array}$ & $\begin{array}{c}1092 \\
\text { HCWs }\end{array}$ & $\begin{array}{l}\text { Socioecological predictors of mental } \\
\text { health outcomes in HCWs during the } \\
\text { COVID-19 pandemic }\end{array}$ \\
\hline
\end{tabular}

$\begin{array}{lcc}\begin{array}{l}\text { Mosheva } \\ \text { et al. 2021 }\end{array} & \begin{array}{c}\text { Israel } \\ \text { April } 19^{\text {th }} \text { to } \\ \text { [24] }\end{array} & \begin{array}{r}\text { Online, } \\ \text { cross- }\end{array} \\ & 2020 & \text { sectiona } \\ & \text { survey }\end{array}$
Comparison of PTSS, depression, and
anxiety in FLHCWs vs. non-FLHCWs
during the COVID-19 pandemic
Key outcomes

(i) High prevalence of anxiety, depression, acute stress symptoms (ii) Increased risk of psychological distress in females, FLHCWs, and paramedical staff; feeling of having insufficient PPE; having experienced the death of a close person from COVID-19

(i) High level of PTS symptoms

(ii) Females, nurses, and FLHCWs have higher risk

(iii) Perceived threat and passive coping increase risk for PTS

(i) Doctors and nurses had lower anxiety levels than administrative personnel

(ii) Lower depression if bachelor's degree or above

(iii) Negative coping mechanisms significantly correlated with anxiety/ depression

(i) Higher levels of PTSD: female gender, lower team cohesion, higher levels of social stigmatization, higher media exposure

(i) Anxiety and depression similar in both FL- and non-FLHCWs

(ii) FLHCWs: higher risk of witnessing patient death, associated with higher PTSS

(iii) Increased anxiety and depression with increased worry about being infected, worry about infecting family, mental exhaustion

\begin{tabular}{|c|c|c|c|c|c|}
\hline $\begin{array}{l}\text { Yi et al. } \\
2020[25]\end{array}$ & $\begin{array}{l}\text { China } \\
\text { April } 26^{\text {th }} \text { to } \\
\text { May } 9^{\text {th }} 2020\end{array}$ & $\begin{array}{l}\text { Online, } \\
\text { cross- } \\
\text { sectional } \\
\text { survey }\end{array}$ & 723 HCWs & $\begin{array}{c}\text { Psychosomatic status in different } \\
\text { groups of HCWs during the COVID- } \\
19 \text { pandemic }\end{array}$ & $\begin{array}{l}\text { (i) Poorer mental health with intensity of } \\
\text { contact with COVID-19 patients, higher } \\
\text { occupational pressure }\end{array}$ \\
\hline $\begin{array}{l}\text { Barua } \\
\text { et al. } 2020 \\
{[26]}\end{array}$ & $\begin{array}{l}\text { Bangladesh } \\
\text { April } 1^{\text {st }} \text { to } \\
\text { May } 30^{\text {th }} \\
2020\end{array}$ & $\begin{array}{l}\text { Online, } \\
\text { cross- } \\
\text { sectional } \\
\text { survey }\end{array}$ & $\begin{array}{l}370 \\
\text { frontline } \\
\text { doctors }\end{array}$ & $\begin{array}{c}\text { Anxiety, depression, sleep disturbance, } \\
\text { and fear of COVID-19 among frontline } \\
\text { doctors }\end{array}$ & $\begin{array}{l}\text { (i) Inadequate resources to provide for } \\
\text { patients contribute most to poor mental } \\
\text { health symptoms }\end{array}$ \\
\hline $\begin{array}{l}\text { Mohd } \\
\text { Noor et al. } \\
2021[27]\end{array}$ & $\begin{array}{l}\text { Malaysia } \\
\text { May to July } \\
2020\end{array}$ & $\begin{array}{l}\text { Online } \\
\text { cross- } \\
\text { sectional } \\
\text { survey, } \\
\text { comparative }\end{array}$ & 306 HCWs & $\begin{array}{l}\text { Anxiety in FLHCWs vs. non-FLHCWs } \\
\text { during the COVID-19 pandemic }\end{array}$ & $\begin{array}{l}\text { (i) Higher levels of anxiety were reported } \\
\text { in the group of non-FLHCWs }\end{array}$ \\
\hline $\begin{array}{l}\text { Shen et al. } \\
2021[28]\end{array}$ & $\begin{array}{l}\text { China } \\
\text { March } 3^{\text {rd }} \text { to } \\
\text { March } 10^{\text {th }} \\
2020\end{array}$ & $\begin{array}{l}\text { Online } \\
\text { cross- } \\
\text { sectional } \\
\text { survey }\end{array}$ & $\begin{array}{l}643 \\
\text { frontline } \\
\text { nurses }\end{array}$ & $\begin{array}{l}\text { Levels of anxiety among frontline } \\
\text { nurses during the COVID-19 } \\
\text { pandemic and its association with } \\
\text { insomnia and perceived stress }\end{array}$ & $\begin{array}{l}\text { (i) High levels of anxiety correlated with } \\
\text { insomnia, perceived stress, night shifts, } \\
\text { fear of COVID-19, having experienced } \\
\text { previous pandemics }\end{array}$ \\
\hline $\begin{array}{l}\text { Cag et al. } \\
2021[29]\end{array}$ & $\begin{array}{l}\text { International } \\
\quad(75 \\
\text { countries }) \\
\text { March } 18^{\text {th }} \text { to } \\
\text { April } 1^{\text {st }} 2020\end{array}$ & $\begin{array}{l}\text { Online, } \\
\text { cross- } \\
\text { sectional } \\
\text { survey }\end{array}$ & $\begin{array}{c}1416 \\
\text { HCWs }\end{array}$ & $\begin{array}{l}\text { Anxiety levels in international HCWs } \\
\text { during the COVID-19 pandemic }\end{array}$ & $\begin{array}{l}\text { (i) Increased anxiety with inadequate } \\
\text { resources, female gender, young age, } \\
\text { insufficient knowledge of COVID-19, } \\
\text { living in high-income countries }\end{array}$ \\
\hline
\end{tabular}


TABLE 1: Continued.

\begin{tabular}{|c|c|c|c|c|c|}
\hline Reference & $\begin{array}{l}\text { Location and } \\
\text { date range }\end{array}$ & Study type & $\begin{array}{l}\text { Sample } \\
\text { size }\end{array}$ & Topic of study & Key outcomes \\
\hline $\begin{array}{l}\text { Tiete et al. } \\
2020[30]\end{array}$ & $\begin{array}{l}\text { Belgium } \\
\text { April } 17^{\text {th }} \text { to } \\
\text { May } 25^{\text {th }} \\
2020\end{array}$ & $\begin{array}{l}\text { Online, } \\
\text { cross- } \\
\text { sectional } \\
\text { survey }\end{array}$ & 647 HCWs & $\begin{array}{l}\text { Differences in mental health between } \\
\text { FLHCWs and non-FLHCWs }\end{array}$ & $\begin{array}{l}\text { (i) High prevalence of anxiety, } \\
\text { depression, and insomnia, no significant } \\
\text { difference between FL and non-FLHCWs } \\
\text { (ii) Worse mental health outcomes: } \\
\text { nurses, young age, working in isolation } \\
\text { wards, increased workloads }\end{array}$ \\
\hline $\begin{array}{l}\text { Lasalvia } \\
\text { et al. } 2021 \\
{[31]}\end{array}$ & $\begin{array}{l}\text { Italy } \\
\text { April } 21^{\text {st }} \text { to } \\
\text { May } 6^{\text {th }} 2020\end{array}$ & $\begin{array}{l}\text { Online, } \\
\text { cross- } \\
\text { sectional } \\
\text { survey }\end{array}$ & $\begin{array}{c}1961 \\
\text { HCWs }\end{array}$ & $\begin{array}{l}\text { Burnout levels and risk factors in } \\
\text { HCWs working during the COVID-19 } \\
\text { pandemic }\end{array}$ & $\begin{array}{l}\text { (i) High risk of burnout: junior doctors } \\
\text { working in FL settings, interpersonal } \\
\text { avoidance, conflicts in the workplace, } \\
\text { increased workload }\end{array}$ \\
\hline $\begin{array}{l}\text { Lai et al. } \\
2020[32]\end{array}$ & $\begin{array}{l}\text { China } \\
\text { January } 29^{\text {th }} \\
\text { to February } \\
3^{\text {rd }} 2020\end{array}$ & $\begin{array}{l}\text { Online, } \\
\text { cross- } \\
\text { sectional } \\
\text { survey }\end{array}$ & $\begin{array}{l}1257 \\
\text { HCWs }\end{array}$ & $\begin{array}{l}\text { Mental health outcomes and associated } \\
\text { factors in HCWs during the COVID- } \\
19 \text { pandemic }\end{array}$ & $\begin{array}{l}\text { (i) Poorer mental health outcomes: } \\
\text { nurses, women, and FLHCWs }\end{array}$ \\
\hline $\begin{array}{l}\text { Hu et al. } \\
2020[33]\end{array}$ & $\begin{array}{l}\text { China } \\
\text { February } 13^{\text {th }} \\
\text { to February } \\
24^{\text {th }} 2020\end{array}$ & $\begin{array}{l}\text { Online, } \\
\text { cross- } \\
\text { sectional } \\
\text { survey }\end{array}$ & $\begin{array}{l}2014 \\
\text { frontline } \\
\text { nurses }\end{array}$ & $\begin{array}{l}\text { Mental health outcomes and associated } \\
\text { factors in frontline nurses caring for } \\
\text { COVID-19 patients }\end{array}$ & $\begin{array}{l}\text { (i) Lack of social support is correlated } \\
\text { with negative mental health outcomes } \\
\text { (ii) Willingness to participate in frontline } \\
\text { work is negatively correlated with } \\
\text { burnout, stress, and anxiety }\end{array}$ \\
\hline
\end{tabular}

of the COVID-19 pandemic, little was known about the risk of SARS-CoV-2 infection. One month after the initial cluster of cases was reported in Wuhan, China, the WHO first confirmed human-to-human transmission of the virus. Healthcare workers tasked with evaluating and treating suspected or confirmed cases were intensely exposed to this novel disease, even before the optimization of transmission prevention. Nguyen et al. found a significant correlation between PPE (Personal Protective Equipment) adequacy and the risk of testing positive for COVID-19. The supply of PPE was severely disrupted, especially in the early stages of the pandemic [38]. This shortage was reflected on a global scale [39].

At the pandemic's height, the shortage of resources, such as ventilators and ICU beds, made the consideration of rationing a necessity. Rationing is defined as the allocation of limited resources. In healthcare, this ultimately results in withholding of treatment from patients that may have potentially benefited. A substantial ethical dilemma exists for the individuals charged with making this decision [40].

The absence of an effective treatment for the COVID-19 illness increases the emotional burden of caring for infected patients. Physicians treating COVID-19 patients have had to cope with the difficulty of caring for often severely ill individuals with few options to propose. In addition, they have had to keep up with emerging knowledge and information and follow the rapidly changing recommendations and institutional policies [26].

FLHCWs have also been faced with marginalization in the community. HCWs have previously reported societal stigmatization and avoidance due to working directly with infected individuals during the SARS epidemic [41]. One study found that FLHCWs feeling higher levels of negative stigma in the community were more likely to report PTSD and alcohol use disorder symptoms [23].
A survey conducted in April 2021 by the Washington Post among FLHCWs evaluated the current subjective state of this population [42]. Not surprisingly, a high mental health burden was also found. However, $76 \%$ of the 1327 HCWs interviewed also reported feeling hopeful about the future. Majorities reported feeling optimistic and motivated when going to work. These findings are encouraging and paint a positive picture of the future.

4.2. Psychological Conditions in HCWs. Healthcare professionals are affected by high levels of stress, burnout, and other mental health conditions compared to other professions [43]. During a global health crisis, as working conditions are increasingly challenging, it is predictable that healthcare professionals will experience an increase in psychological stressors.

The relationship between stress and mental health conditions has been well studied. Acute stress responses can be adaptive and appropriate in certain situations. However, negative effects can ensue when the exposure to a stressor is prolonged or particularly intense. Evidence supports the existence of a causal link between depression and negative life events $[44,45]$. Similar evidence exists for other mental health conditions such as GAD. A study on individuals directly affected by hurricanes showed a measurable biological and psychological impact with an increased risk of GAD [46]. An important element to note is that the response to stress can vary widely between different individuals exposed to the same stressor. It is therefore essential to identify the factors that favor poorer outcomes in order to effectively target preventative measures.

Several interacting factors contribute to determining what psychological effects a challenging situation will have on an individual. These factors are commonly divided into four distinct dimensions: individual (gender, age, previous 
TABLE 2

\begin{tabular}{|c|c|}
\hline Psychological condition & Factors associated with higher risk \\
\hline Depression and anxiety & $\begin{array}{l}\text { Individual/interpersonal factors } \\
\text { (i) Female gender }[14,18,29,32,34] \\
\text { (ii) Young age [18, 20,29, 30,34] } \\
\text { (iii) Attention to negative information about the pandemic [13] } \\
\text { (iv) Poor coping mechanisms [22] } \\
\text { (v) Having experienced a previous pandemic [28] } \\
\text { (vi) Lower level of education [22] } \\
\text { (vii) Insufficient knowledge of COVID-19 [29] } \\
\text { Institutional factors } \\
\text { (i) Frontline work [12-14, 16, 18, 20, 28-30, 32, 35] } \\
\text { (ii) Nonfrontline work [27] } \\
\text { (iii) Loss of a patient due to COVID-19 [34] } \\
\text { (iv) Loss of a close person from COVID-19 [20] } \\
\text { (v) Higher workload [25] } \\
\text { (vi) Less work experience [18] } \\
\text { (vii) Lack of PPE or resources in the workplace [20, 26, 29] } \\
\text { (viii) Administrative or paramedical work [20, 22] } \\
\text { (ix) Working as a nurse [13, 16, 30, 32] } \\
\text { Community factors } \\
\text { (i) High media exposure [23] } \\
\text { (ii) High-income countries [29] } \\
\text { (iii) Lack of social support [33] }\end{array}$ \\
\hline
\end{tabular}

Individual/interpersonal factors

(i) Female gender $[21,23,30,32]$

(ii) Young age $[30,34]$

(iii) Passive coping strategies [21]

(iv) Anxiety about being infection [24]

Institutional factors

Posttraumatic stress disorder

(i) Frontline work [12, 21, 32]

(ii) Loss of a patient due to COVID-19 [24, 34]

(iii) Higher workload [25]

(iv) Lower team cohesion [23]

(v) Working as a nurse [21]

Community factors

(i) High media exposure [23]

(ii) Social stigmatization [23, 33]

Individual/interpersonal factors

(i) Young age $[30,31]$

(ii) Higher alcohol intake [19]

(iii) Unwillingness to participate in frontline work [33]

(iv) Attention to negative information about the pandemic [13]

Burnout Institutional factors

(i) Frontline work [12, 13, 19, 30-32]

(ii) Higher workload [30, 31]

(iii) Less work experience [31]

(iv) Lack of PPE or resources in the workplace $[19,26]$

(v) Conflicts in the workplace [31]

Individual/interpersonal factors

(i) Female gender $[14,15,32]$

(ii) Education level of high school or less [17]

(iii) Attention to negative information about the pandemic [13]

Insomnia Institutional factors

(i) Frontline work [13, 14, 32, 35]

(ii) Nonphysician healthcare workers [15]

(iii) Physicians [17]

(iv) Higher workload [25]

(v) Uncertainty about disease control [17] 
mental health, and others), interpersonal (social support), institutional (workplace conditions), and community factors (stigma or support). It is essential to identify the adverse psychological effects on HCWs in intense stress situations such as the current pandemic (Table 2).

Although the extent of the COVID-19 pandemic has been much more significant than previous viral pandemics of this century, looking at past events may provide valuable information for our present situation. Both during the 2002-2004 SARS-Cov-1 epidemic and the MERS-CoV outbreak first detected in 2012, healthcare workers' mental health was closely scrutinized. Similarly to the current situation, healthcare workers in contact with SARS-CoV-1 reported high levels of stress and mental health conditions [11]. A study conducted during a 2015 MERS outbreak showed higher levels of PTSD in FLHCWs as well as quarantined patients [47] As early as 2003, risk factors were identified and preventative measures were proposed to avert similar outcomes in the future [48]. Unfortunately, the current data shows that mental health in FLHCWs is as poor, if not worse, than in FLHCWs during the previous epidemics. It is therefore more urgent than ever to develop and implement effective strategies to prevent these outcomes in the future.

4.2.1. Depression and Anxiety. Symptoms of anxiety and depression were evaluated by most studies included in this review. They are closely related, and risk factors frequently overlap.

Previous studies conducted outside of the current pandemic have shown high levels of anxiety and depression in healthcare workers. Depression or depressive symptoms were found among $20-40 \%$ of resident physicians in a meta-analysis conducted in 2015 [49]. Similarly, $18 \%$ of hospital-employed nurses screened positive for depression in a 2012 survey [50]. Anxiety is also highly prevalent in HCWs and particularly common in emergency medical personnel [51]. Notably, studies have found that screening positive for anxiety or depression is associated with a significantly higher incidence of adverse safety outcomes in the healthcare setting [52].

These findings are consistent with what was reported by the majority of studies included in this review. As previously mentioned, most studies found a higher prevalence of GAD and depressive symptoms in FLHCWs than other HCWs.

Other risk factors were expected, as they are known to predispose an individual to GAD or depression, even outside of working in healthcare or a pandemic environment. Being of the female gender, younger age, and having a chronic illness or previous mental health disorder are known risk factors for poor mental health [53].

Working conditions were also determined to play an important role. Almost all studies found a higher prevalence of anxiety and depression in healthcare workers involved in frontline work. The risk of anxiety and depression increased when caring for more COVID-19 patients and with higher amounts of weekly working hours. Participants were also more likely to report symptoms of depression and anxiety if they felt a lower level of support from peers and supervi- sors and if they reported feeling less competent in caring for COVID-19 patients [18]. Having insufficient PPE to protect oneself and a lack of resources to care for patients were identified as two significant risk factors for anxiety and depression $[26,29]$.

One study conducted in Malaysia that specifically compared anxiety levels in FLHCW vs. non-FLHCWs found that non-FLHCWs had lower anxiety levels. The authors present the theory that FLHCWs generally have easier access to updated first-hand medical information on the virus and the pandemic [27]. The results of other studies have supported this theory by showing that anxiety levels were lower in individuals that reported being well informed about the pandemic or in individuals with higher levels of education $[29,22]$.

Low levels of trust in the government response to the pandemic and increased media exposure were also associated with GAD [23]. These findings suggest that developing an effective national response to an infectious disease outbreak may reduce the psychological effects on FLHCWs.

A survey conducted among FLHCWs found that individuals with higher anxiety and depression scores generally adopted harmful coping mechanisms and had lower selfefficacy than the group without negative psychology [22]. Active coping mechanisms that prevent adverse psychological reactions can be taught and learned and may represent an essential element to incorporate in mitigating adverse mental health outcomes on FLHCWs in the future.

These findings suggest several measures that may effectively reduce adverse mental health outcomes for FLHCWs. Limited working hours and a reduced patient load should be implemented whenever possible. Increasing support from management tiers of the healthcare establishment and providing easy and direct access to updated information to employees may reduce anxiety and depression levels. Furthermore, providing adequate PPE is crucial to reduce anxiety and increase confidence in healthcare workers.

4.2.2. Posttraumatic Stress Disorder (PTSD). In the context of previous viral epidemics such as SARS, it has been shown that FLHCWs had a higher prevalence of and more severe PTSD symptoms than other healthcare professionals [9]. A study assessing the long-term psychological effects of frontline work during the SARS outbreak in Hong-Kong HCWs did not find a higher level of perceived stress in FLHCWs. However, when reassessed at one year, high-risk HCWs had a significantly higher prevalence of chronic stress, PTSD, and other adverse mental health outcomes [11].

A survey conducted in Italian HCWs by Trumello et al. during the COVID-19 outbreak assessed perceived stress levels using the same scale used in the prior survey conducted by McAlonan et al. during the SARS epidemic [12]. As previously mentioned, the SARS FLHCWs showed significantly higher PTSD levels at one-year follow-up than other HCWs. The results identified by Trumello et al., therefore, may suggest that the prevalence of PTSD symptoms may continue to increase even after the acute phase of the pandemic passes. This study also showed that FLHCWs were twice as likely to seek psychological support as non- 
FLHCWs, suggesting that preventative programs would be sought out and potentially beneficial for these individuals.

Witnessing patient death while working in the COVID19 sector was identified as a factor that may explain the higher prevalence of PTSD symptoms in FLHCWs. A survey of HCWs in Israel found a fourfold increase in PTSS (Posttraumatic stress syndrome) in HCWs that witnessed patient death while caring for COVID-19 patients [24]. Most healthcare workers are exposed to the passing of patients as a part of their professional lives. However, COVID-19 is known to be fatal even in relatively young and healthy individuals. Especially in certain extremely hard-hit areas throughout the pandemic, the volume of sick patients and patient deaths reached unprecedented and previously unseen levels, even for experienced HCWs [54].

A survey conducted among Chinese healthcare professionals found that PTSS were positively correlated with passive coping mechanisms and negatively correlated with active coping mechanisms [21]. This finding is encouraging, as it suggests that promoting the development of coping mechanisms in FLHCWs may reduce the incidence of PTSD development.

4.2.3. Burnout. It has been previously shown that medical professionals are at particularly high risk for burnout. The syndrome is associated with adverse personal effects such as substance abuse, relationship difficulties, and even suicide. Professional ramifications are also common, such as increased medical errors, lower patient satisfaction, and reduced quality of care [55]. A survey conducted in 2011 evaluated burnout and job satisfaction levels in U.S. physicians. The study found that physicians were more likely to have burnout symptoms (37.9\% vs. $27.8 \%)$ than a representative sample of the adult U.S. working public. The prevalence was particularly elevated in physicians working in the first line of care, such as emergency medicine specialists or general practitioners [43].

According to a study by Macía-Rodríguez et al., 40\% of Spanish internists working as part of the COVID-19 response screened positive for burnout. Several other studies reported similar levels [31, 30, 33]. Independent risk factors included working directly with COVID-19+ patients and overtime work without compensation, as well as the fear of infecting relatives [19]. These levels of burnout syndrome are a reason for concern as they are known to translate to poorer patient outcomes.

A prospective cohort study conducted in Scotland from March to June 2020 found a significantly increased risk of hospitalization for COVID-19 in household members of FLHCW [56]. Due to this risk, FLHCWs often chose to remain separated from their families and friends to reduce the risk of infection. Isolation from the social circle, which generally represents a source of comfort and support, significantly increases psychological pressure on these individuals. The risk of burnout in FLHCWs was significantly more elevated in individuals that chose to move out of their family homes while doing frontline work [31].

As previously mentioned, FLHCWs often experience stigmatization in the community due to their heightened exposure and risk for infection. One survey found that HCWs that reported social avoidance due to their profession were also more likely to report higher levels of burnout [31].

4.2.4. Insomnia. The association between insomnia and poor mental and physical health has been extensively characterized in the past [57]. It is known that poor sleep quality and insomnia contribute to lower professional performance [58].

FLHCWs reported longer sleep latency, shorter sleep duration, lower sleep efficiency, and worse daytime function [14]. Female participants were more vulnerable to sleep disturbances. As for anxiety and depression, insomnia was more common in nurses and other nonphysician HCWs $[15,17]$. This may stem from the fact that physicians generally tend to have access to more current and updated information on the pandemic and the pathogen in question. By the nature of their work, nurses may have the most intense and consistent exposure to infected patients. Nurses that reported fear of COVID-19 were more prone to experience insomnia. Not surprisingly, an increasing number of night shifts or longer working hours also contributed to a higher prevalence of insomnia [28]. Receiving negative feedback from family and friends about joining frontline work increased the risk for poor sleep quality [13]. These findings are particularly concerning when considering that there is some evidence that sleep deprivation may represent an independent risk factor for COVID-19 infection [59].

As insomnia is closely related to, and correlated with, other mental health conditions such as anxiety, depression, and PTSD, it is probable that when implementing strategies to reduce these psychological conditions in FLHCWs, the prevalence of insomnia will decrease in parallel.

4.3. Solutions/Future Perspectives. Review of the current literature identified several groups of FLHCWs that are particularly vulnerable to poor mental health due to pandemic-related challenges inside and outside the workplace. Intrinsic factors may predispose an individual to poor mental health. The female gender is a known risk factor for many mental health conditions [53]. However, in the context of this global pandemic, there may be additional contributing factors to consider. With lockdowns imposed by many governments, schooling duties, parenting, and household duties have shifted from teachers, sitters, and household aids back to parents. Women have disproportionately taken on these responsibilities, frequently in addition to full-time jobs [60]. Younger, less experienced individuals and those with preexisting mental health conditions were also shown to be part of higher-risk groups for poor mental health outcomes [34, 18]. Awareness of risk factors in specific individuals will permit targeting preventative strategies effectively.

Feeling insufficient support from superiors in the workplace or the healthcare institution was a commonly identified factor predisposing to all adverse psychosomatic outcomes in FLHCWs [23]. The CDC has provided recommendations for healthcare personnel to improve coping and improve resilience during the pandemic [61]. Maintaining adequate mental health in FLHCWs is essential for an effective response to a 
global infectious disease outbreak. These recommendations should therefore be integrated when revising or creating guidelines for future pandemic responses.

The overwhelming majority of the literature found a positive correlation between increased occupational pressure and poor mental health. Multiple studies emphasized the importance of improving workplace conditions for FLHCWs, such as reducing work hours, improving medical equipment supply, and reducing congestion in wards [25, 31, 29].

A study on Chinese healthcare workers was aimed at developing individual growth from posttraumatic stress by implementing a novel psychological intervention. Posttraumatic growth is defined as a positive psychological change developed in response to coping with challenging circumstances. The study showed that the intervention induced positive effects in HCWs. An increased effect was seen in women, nurses, and college graduates [62]. These findings suggest that the implementation of psychological interventions can limit negative outcomes in FLHCWs and may even achieve increased psychological resilience.

4.4. Limitations. Several limitations of this review must be noted. First, the literature review was conducted in the English language, and only papers available in English were included.

The large majority of studies included in this review were designed as voluntary online questionnaires. Therefore, a significant sampling bias cannot be ruled out when including exclusively volunteers. All studies included in this review reported a majority of female responders. As mentioned, the female gender is an independent risk factor for many mental health conditions. It is not unlikely that the prevalence of mental health conditions may be overestimated due to the sampling bias and may not be entirely representative of healthcare workers as a whole. All studies were crosssectional in design. This design does not allow for the determination of the causal relationships that may exist. Overall, the results reported in this review were identified by several studies and were coherent and plausible when considering previous research, therefore increasing confidence in the results.

\section{Conclusion}

Worldwide, thousands of FLHCWs have died due to infection with COVID-19 [63]. Healthcare workers and their family members are significantly more likely to be infected and hospitalized with COVID-19 than members of the general public [37]. Novel and unprecedented challenges in the workplace and daily life have resulted in a significant and concerning psychological impact on our FLHCWs. Although no significant difference in mental health problems was reported before the pandemic, frontline medical staff tend to report higher levels of anxiety, depression, sleep problems, and lower quality of life since the outbreak. Psychosomatic issues are also more prevalent with increasing levels of exposure to COVID-19 patients [25]. Maintaining the mental and physical health of FLHCWs is crucial for an effective response to a global pandemic. Increasing awareness of the intrinsic and environmental risk factors predisposing healthcare workers to adverse mental health outcomes is crucial to target interventions that are aimed at managing these conditions in future situations of extraordinary strain on healthcare systems.

\section{Abbreviations}

AIS: $\quad$ Athens Insomnia Scale

AUD: $\quad$ Alcohol use disorder

COVID-19: Coronavirus disease of 2019

DASS-21: Depression, Anxiety and Stress Scale 21

DSM-V: Diagnostic and Statistical Manual of Mental

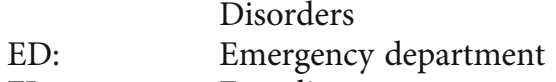

FL: $\quad$ Frontline

FLHCWs: Frontline healthcare workers

GAD: $\quad$ Generalized anxiety disorder

GAD-7: $\quad$ General anxiety disorder 7

HADS: Hospital Anxiety and Depression Scale

HCWs: Healthcare workers

ISI: Insomnia Severity Index

MERS: $\quad$ Middle East respiratory syndrome

MD: $\quad$ Major depression

OH: $\quad$ Alcohol

PHQ-9: Patient health questionnaire

PPE: $\quad$ Personal protective equipment

PRISMA: Preferred reporting items for systematic

$\begin{array}{ll} & \text { reviews and meta-analyses } \\ \text { PSQI: } & \text { Pittsburgh Sleep Quality Index }\end{array}$

PTS: $\quad$ Posttraumatic stress

PTSD: $\quad$ Posttraumatic stress disorder

PTSS: $\quad$ Posttraumatic stress symptoms

SARS-CoV-1: Severe acute respiratory syndrome coronavirus 1

SARS-CoV-2: Severe acute respiratory syndrome coronavirus 2

vs.: $\quad$ Versus

WHO: World Health Organization.

\section{Data Availability}

The data supporting this systematic review are from previously reported studies and datasets, which have been cited. Please refer to Table 1 in the manuscript for this data.

\section{Conflicts of Interest}

The authors declare that they have no conflicts of interest.

\section{References}

[1] M. Nicola, Z. Alsafi, C. Sohrabi et al., "The socio-economic implications of the coronavirus pandemic (COVID-19): a review," International Journal of Surgery, vol. 78, pp. 185193, 2020.

[2] L. Dong and J. Bouey, "Public mental health crisis during COVID-19 Pandemic, China," Emerging Infectious Diseases, vol. 26, no. 7, pp. 1616-1618, 2020.

[3] B. N. Kantor and J. Kantor, "Mental health outcomes and associations during the COVID-19 pandemic: a cross-sectional 
population-based study in the United States," Frontiers in Psychiatry, vol. 11, 2020.

[4] American Psychiatric Association, "Anxiety disorders," in Diagnostic and Statistical Manual of Mental Disorders, DSM Library, Washington DC, 5th edition, 2013.

[5] American Psychiatric Association, "Depressive disorders," in Diagnostic and Statistical Manual of Mental Disorders, DSM Library, Washington DC, 5th edition, 2013.

[6] American Psychiatric Association, "Trauma- and stressorrelated disorders," in Diagnostic and Statistical Manual of Mental Disorders, DSM Library, Washington DC, 5th edition, 2013.

[7] C. Maslach, W. B. Schaufeli, and M. P. Leiter, "Job burnout," Annual Review of Psychology, vol. 52, no. 1, pp. 397-422, 2001.

[8] American Psychiatric Association, "Sleep-wake disorders," in Diagnostic and Statistical Manual of Mental Disorders, DSM Library, Washington DC, 5th edition, 2013.

[9] C.-Y. Lin, Y.-C. Peng, Y.-H. Wu, J. Chang, C.-H. Chan, and D.-Y. Yang, "The psychological effect of severe acute respiratory syndrome on emergency department staff," Emergency Medicine Journal, vol. 24, no. 1, pp. 12-17, 2007.

[10] S. Kisely, N. Warren, L. McMahon, C. Dalais, I. Henry, and D. Siskind, "Occurrence, prevention, and management of the psychological effects of emerging virus outbreaks on healthcare workers: rapid review and meta-analysis," BMJ, vol. 369, article m1642, 2020.

[11] G. M. McAlonan, A. M. Lee, V. Cheung et al., "Immediate and sustained psychological impact of an emerging infectious disease outbreak on health care workers," Canadian Journal of Psychiatry, vol. 52, no. 4, pp. 241-247, 2007.

[12] C. Trumello, S. M. Bramanti, G. Ballarotto et al., "Psychological adjustment of healthcare workers in Italy during the COVID-19 pandemic: differences in stress, anxiety, depression, burnout, secondary trauma, and compassion satisfaction between frontline and non-frontline professionals," International Journal of Environmental Research and Public Health, vol. 17, no. 22, p. 8358, 2020.

[13] J. Que, L. Shi, J. Deng et al., "Psychological impact of the COVID-19 pandemic on healthcare workers: a crosssectional study in China," General Psychiatry, vol. 33, no. 3, p. e100259, 2020.

[14] J. Qi, J. Xu, B. Li et al., "The evaluation of sleep disturbances for Chinese frontline medical workers under the outbreak of COVID-19," medRxiv, vol. 72, 2020.

[15] H. Jahrami, A. S. BaHammam, H. AlGahtani et al., “The examination of sleep quality for frontline healthcare workers during the outbreak of COVID-19," Sleep \& Breathing, vol. 25, no. 1, pp. 503-511, 2021.

[16] Y. An, Y. Yang, A. Wang et al., "Prevalence of depression and its impact on quality of life among frontline nurses in emergency departments during the COVID-19 outbreak," Journal of Affective Disorders, vol. 276, pp. 312-315, 2020.

[17] C. Zhang, L. Yang, S. Liu et al., "Survey of insomnia and related social psychological factors among medical staff involved in the 2019 novel coronavirus disease outbreak," Frontiers in Psychiatry, vol. 11, 2020.

[18] R. Y. Elbay, A. Kurtulmuş, S. Arpacioğlu, and E. Karadere, "Depression, anxiety, stress levels of physicians and associated factors in Covid-19 pandemics," Psychiatry Research, vol. 290, p. $113130,2020$.

[19] C. Macía-Rodríguez, Á. Alejandre de Oña, D. Martín-Iglesias et al., "Burn-out syndrome in Spanish internists during the
COVID-19 outbreak and associated factors: a crosssectional survey," BMJ Open, vol. 11, no. 2, article e042966, 2021.

[20] J. Erquicia, L. Valls, A. Barja et al., "Emotional impact of the Covid-19 pandemic on healthcare workers in one of the most important infection outbreaks in Europe," Medicina Clínica, vol. 155, no. 10, pp. 434-440, 2020.

[21] M.-Y. Si, X.-Y. Su, Y. Jiang et al., "Psychological impact of COVID-19 on medical care workers in China," Infectious Diseases of Poverty, vol. 9, no. 1, p. 113, 2020.

[22] Y. Xia, H. Zhang, Y. Xia, H. Li, L. Zhai, and H. Wang, "The self-psychological safety maintenance and its influencing factors of community frontline staff during COVID-19 pandemic," Medicine, vol. 100, no. 3, article e24140, 2021.

[23] R. Hennein, E. J. Mew, and S. R. Lowe, "Socio-ecological predictors of mental health outcomes among healthcare workers during the COVID-19 pandemic in the United States," PLoS One, vol. 16, no. 2, article e0246602, 2021.

[24] M. Mosheva, R. Gross, N. Hertz-Palmor et al., "The association between witnessing patient death and mental health outcomes in frontline COVID-19 healthcare workers," Depression and Anxiety, vol. 38, no. 4, pp. 468-479, 2021.

[25] J. Yi, L. Kang, J. Li, and J. Gu, "A key factor for psychosomatic burden of frontline medical staff: occupational pressure during the COVID-19 pandemic in China," Frontiers in Psychiatry, vol. 11, p. 590101, 2020.

[26] L. Barua, M. S. Zaman, F. R. Omi, and M. Faruque, "Psychological burden of the COVID-19 pandemic and its associated factors among frontline doctors of Bangladesh: a crosssectional study," F1000Res, vol. 9, p. 1304, 2020.

[27] N. Mohd Noor, R. Che Yusof, and M. A. Yacob, “Anxiety in frontline and non-frontline healthcare providers in Kelantan, Malaysia," International Journal of Environmental Research and Public Health, vol. 18, no. 3, p. 861, 2021.

[28] Y. Shen, Y. Zhan, H. Zheng, H. Liu, Y. Wan, and W. Zhou, "Anxiety and its association with perceived stress and insomnia among nurses fighting against COVID-19 in Wuhan: a cross-sectional survey," Journal of Clinical Nursing, vol. 30, no. 17-18, pp. 2654-2664, 2021.

[29] Y. Cag, H. Erdem, A. Gormez et al., “Anxiety among front-line health-care workers supporting patients with COVID-19: a global survey," General Hospital Psychiatry, vol. 68, pp. 9096, 2021.

[30] J. Tiete, M. Guatteri, A. Lachaux et al., "Mental health outcomes in healthcare workers in COVID-19 and nonCOVID-19 care units: a cross-sectional survey in Belgium," Frontiers in Psychology, vol. 11, p. 612241, 2021.

[31] A. Lasalvia, F. Amaddeo, S. Porru et al., "Levels of burn-out among healthcare workers during the COVID-19 pandemic and their associated factors: a cross-sectional study in a tertiary hospital of a highly burdened area of north-East Italy," BMJ Open, vol. 11, no. 1, article e045127, 2021.

[32] J. Lai, S. Ma, Y. Wang et al., "Factors associated with mental health outcomes among health care workers exposed to coronavirus disease 2019," JAMA Network Open, vol. 3, no. 3, article e203976, 2020.

[33] D. Hu, Y. Kong, W. Li et al., "Frontline nurses' burnout, anxiety, depression, and fear statuses and their associated factors during the COVID-19 outbreak in Wuhan, China: A largescale cross-sectional study," EClinicalMedicine., vol. 24, p. 100424, 2020. 
[34] C. Conti, L. Fontanesi, R. Lanzara, I. Rosa, and P. Porcelli, "Fragile heroes. The psychological impact of the COVID-19 pandemic on health-care workers in Italy," PLoS One, vol. 15, no. 11, article e0242538, 2020.

[35] Q. Cai, H. Feng, J. Huang et al., "The mental health of frontline and non-frontline medical workers during the coronavirus disease 2019 (COVID-19) outbreak in China: a case-control study," Journal of Affective Disorders, vol. 275, pp. 210-215, 2020.

[36] M. Nyashanu, F. Pfende, and M. Ekpenyong, "Exploring the challenges faced by frontline workers in health and social care amid the COVID-19 pandemic: experiences of frontline workers in the English Midlands region, UK," Journal of Interprofessional Care, vol. 34, no. 5, pp. 655-661, 2020.

[37] L. H. Nguyen, D. A. Drew, M. S. Graham et al., "Risk of COVID-19 among front-line health-care workers and the general community: a prospective cohort study," The Lancet Public Health., vol. 5, no. 9, pp. e475-e483, 2020.

[38] T. Burki, "Global shortage of personal protective equipment," The Lancet Infectious Diseases, vol. 20, no. 7, pp. 785-786, 2020.

[39] X. Ma and D. Vervoort, "Critical care capacity during the COVID-19 pandemic: global availability of intensive care beds," Journal of Critical Care, vol. 58, pp. 96-97, 2020.

[40] A. L. McGuire, M. P. Aulisio, F. D. Davis et al., "Ethical challenges arising in the COVID-19 pandemic: an overview from the Association of Bioethics Program Directors (ABPD) task force," The American Journal of Bioethics., vol. 20, no. 7, pp. 15-27, 2020.

[41] L. A. Nickell, E. J. Crighton, C. S. Tracy et al., "Psychosocial effects of SARS on hospital staff: survey of a large tertiary care institution," CMAJ, vol. 170, no. 5, pp. 793-798, 2004.

[42] "KFF/The Washington Post frontline health care workers survey," KFF. Published April 6, 2021. Accessed June 5, 2021. 2021, http://www.kff.org/coronavirus-covid-19/poll-finding/ kff-washington-post-health-care-workers/.

[43] T. D. Shanafelt, S. Boone, L. Tan et al., "Burnout and satisfaction with work-life balance among US physicians relative to the general US population," Archives of Internal Medicine, vol. 172, no. 18, pp. 1377-1385, 2012.

[44] C. Peterson and M. E. Seligman, "Causal explanations as a risk factor for depression: theory and evidence," Psychological Review, vol. 91, no. 3, pp. 347-374, 1984.

[45] E. S. Paykel, "Stress and affective disorders in humans," Seminars in Clinical Neuropsychiatry, vol. 6, no. 1, pp. 4-11, 2001.

[46] A. B. Amstadter, K. C. Koenen, K. J. Ruggiero et al., "NPY moderates the relation between hurricane exposure and generalized anxiety disorder in an epidemiologic sample of hurricane-exposed adults," Depression and Anxiety, vol. 27, no. 3, pp. 270-275, 2010.

[47] S. M. Lee, W. S. Kang, A.-R. Cho, T. Kim, and J. K. Park, "Psychological impact of the 2015 MERS outbreak on hospital workers and quarantined hemodialysis patients," Comprehensive Psychiatry, vol. 87, pp. 123-127, 2018.

[48] C. W. C. Tam, E. P. F. Pang, L. C. W. Lam, and H. F. K. Chiu, "Severe acute respiratory syndrome (SARS) in Hong Kong in 2003: stress and psychological impact among frontline healthcare workers," Psychological Medicine, vol. 34, no. 7, pp. 11971204, 2004.

[49] D. A. Mata, M. A. Ramos, N. Bansal et al., "Prevalence of depression and depressive symptoms among resident physi- cians: a systematic review and meta-analysis," Journal of the American Medical Association, vol. 314, no. 22, pp. 23732383, 2015.

[50] S. Letvak, C. J. Ruhm, and T. McCoy, "Depression in hospitalemployed nurses," Clinical Nurse Specialist, vol. 26, no. 3, pp. 177-182, 2012.

[51] N. Alharthy, O. A. Alrajeh, M. Almutairi, and A. Alhajri, "Assessment of anxiety level of emergency health-care workers by generalized anxiety disorder-7 tool," International Journal of Applied \& Basic Medical Research, vol. 7, no. 3, pp. 150$154,2017$.

[52] M. D. Weaver, C. Vetter, S. M. W. Rajaratnam et al., "Sleep disorders, depression and anxiety are associated with adverse safety outcomes in healthcare workers: a prospective cohort study," Journal of Sleep Research, vol. 27, no. 6, article e12722, 2018.

[53] A. Riecher-Rössler, "Sex and gender differences in mental disorders," The Lancet Psychiatry., vol. 4, no. 1, pp. 8-9, 2017.

[54] L. Piroth, J. Cottenet, A.-S. Mariet et al., "Comparison of the characteristics, morbidity, and mortality of COVID-19 and seasonal influenza: a nationwide, population-based retrospective cohort study," The Lancet Respiratory Medicine., vol. 9, no. 3, pp. 251-259, 2021.

[55] S. De Hert, "Burnout in healthcare workers: prevalence, impact and preventative strategies," Local Regional Anesthesia, vol. 13, pp. 171-183, 2020.

[56] A. S. V. Shah, R. Wood, C. Gribben et al., "Risk of hospital admission with coronavirus disease 2019 in healthcare workers and their households: nationwide linkage cohort study," BMJ, vol. 371, p. m3582, 2020.

[57] B. Sivertsen, S. Krokstad, S. Øverland, and A. Mykletun, “The epidemiology of insomnia: associations with physical and mental health.: the HUNT-2 study," Journal of Psychosomatic Research, vol. 67, no. 2, pp. 109-116, 2009.

[58] R. C. Kessler, P. A. Berglund, C. Coulouvrat et al., "Insomnia and the performance of US workers: results from the America Insomnia Survey," Sleep, vol. 34, no. 9, pp. 1161-1171, 2011.

[59] L. Ran, X. Chen, Y. Wang, W. Wu, L. Zhang, and X. Tan, "Risk factors of healthcare workers with Coronavirus disease 2019: a retrospective cohort study in a designated hospital of Wuhan in China," Clinical Infectious Diseases, vol. 71, no. 16, pp. 2218-2221, 2020.

[60] R. K. Delaney, A. Locke, M. L. Pershing et al., "Experiences of a health system's faculty, staff, and trainees' career development, work culture, and childcare needs during the COVID-19 pandemic," JAMA Network Open, vol. 4, no. 4, article e213997, 2021.

[61] CDC, Healthcare workers, Centers for Disease Control and Prevention, 2020, Accessed March 19, 2021. https://www.cdc .gov/coronavirus/2019-ncov/hcp/mental-health-healthcare .html.

[62] X. Xu, M. Hu, Y. Song et al., "Effect of positive psychological intervention on posttraumatic growth among primary healthcare workers in China: a preliminary prospective study," Scientific Reports, vol. 6, no. 1, p. 39189, 2016.

[63] H. Erdem and D. R. Lucey, "Healthcare worker infections and deaths due to COVID-19: a survey from 37 nations and a call for WHO to post national data on their website," International Journal of Infectious Diseases, vol. 102, pp. 239-241, 2021. 